DOI 10.18551/rjoas.2021-09.05

\title{
PREDICTION OF FINANCIAL DISTRESS IN MANUFACTURING COMPANIES ON THE INDONESIA STOCK EXCHANGE DURING THE PANDEMIC
}

\author{
Nurrohim Hasa, Herusatoto Shinta \\ UPN “Veteran" Yogyakarta, Indonesia \\ *E-mail: hasa.nurrohim@gmail.com
}

\begin{abstract}
Financial distress is a condition of financial difficulties faced by companies that can lead to bankruptcy. This study seeks to predict the financial distress that may be experienced by the company through testing the influence of the company's financial ratios. By using the Altman Z-score to determine the condition of the company, the results of the study indicate that the ratio of cash position and activity ratio can be used to predict conditions of financial distress.
\end{abstract}

\section{KEY WORDS}

Financial distress, Altman's Z score, financial ratio.

Around 1998, Indonesia underwent political and economic changes. At that time, there was a change of national leadership, accompanied by an economic downturn. Initially, the Indonesian economy grew positively, but during the crisis and post-crisis, economic growth became minus. This condition affects the industrial world, especially the manufacturing industry. The economic crisis has made the Indonesian economy a country that has the worst economy in the world. After the economic crisis, the Indonesian economy began to improve and showed a positive trend.

The economic crisis that hit around 1998 is almost repeated today. The cause is a global virus outbreak pandemic, the spread of the covid 19 viruses. Starting from China, then this outbreak spread throughout the world including Indonesia at around the end of 2019. This pandemic outbreak had an impact on overall economic activity. Companies carry out efficient activities, reduce capacity, and some even close temporarily. Likewise, manufacturing companies experienced a decline in production. The decline in production occurred due to reduced consumer demand. Consumer demand is reduced because consumers can not work at normal times. As a result, consumers do not have the income to buy goods and services. This declining condition has caused economic sluggishness, especially in the manufacturing industry sector (Brahmana, 2007). In addition, loan interest rates also increased, banks also limited credit, imported raw materials also increased, and many letters of credit $(\mathrm{L} / \mathrm{C})$ from national and foreign banks were rejected. funding difficulties, and leading to bankruptcy.

Bankruptcy can be caused by two things, first, there is an imbalance between income and expenditure; second, lack of liquidity or lack of ability to meet obligations as they fall due. The company's financial condition is the main factor for investors and creditors to invest in the company. Thus, prediction and analysis of the company's financial condition is important and must be a concern.

Financial distress leads to a decline in the company's finances (Plat and Plat, 2002). If it happens continuously, then the company is heading towards bankruptcy or liquidation. According to Brahmana (2007), companies experience financial distress due to the company's inability to maintain and manage the company's financial stability. Initially, it was the company's failure to promote its products, causing sales to decline. Then, the company will experience a decrease in revenue, even the company will experience a loss in the current year. Furthermore, there is capital inefficiency so that companies will have difficulty paying dividends, and have difficulty forming their capital through retained earnings. If the company's total liabilities exceed its total assets, the company's burden will be heavier. If the company cannot cope and get out of this situation, the company will go bankrupt, or financial distress. 
Financial statement analysis can be used to identify the condition of financial distress in a company by analyzing the financial ratios owned by the company. Plat and Plat (2002) use financial ratios from the information in the balance sheet and income statement to identify financial distress conditions, while. Luciana (2006) researched by adding financial ratios from the cash flow statement. Furthermore, Brahmana (2007) uses unadjusted financial ratios based on auditor reputation ratings (based on total assets) and industry.

This study was conducted to re-examine the effect of financial ratio variables on company activities in companies in the manufacturing sector for the 2019-2020 period. Hopefully, by knowing the conditions faced by the company, the company will be better prepared and able to overcome the problems encountered. The so it does not lead to state bankruptcy

\section{LITERATURE REVIEW}

There is some understanding of the financial statements, among others, namely:

- The financial report is a report that is the result accounting process that can be used as a means of communication/activity between the company and the parties with an interest in the data/activity of the company (Munawir. S, 1995; Ridwan and Inge, 2001);

- The financial report is an overview of the company's financial condition, which consists of a balance sheet (which includes the value of assets, debt, own capital at a certain time) and a profit and loss statement (results from activities/business for 1 year (Riyanto. Bambang, 1995);

- Financial reports are one of the important sources of information, such as information on the company's market share, quality of management, and others. There are 3 types of financial reports, namely: balance sheet, income statement, and cash flow statement. In addition, there are supporting reports, such as statements of retained earnings and report on changes in the capital (Hanafi. M and Halim. A, 1996);

- The financial report is a summary of a recording process and financial transactions that occurred during the financial year concerned (Munawir. S, 1995).

There are several company ratios based on the balance sheet, income statement, and cash flow statement (Riyanto, 1995), namely:

- Profitability Ratio. Profitability ratio is a ratio that shows k the company's ability to generate profits through existing capabilities and resources;

- Liquidity Ratio. Liquidity ratio is a ratio that shows the company's ability to settle its obligations in the short term. The liquidity ratio used is the current ratio;

- Activity/Efficiency Ratio. The activity/efficiency ratio is a ratio that shows the activities carried out by the company in carrying out its activities/operations, such as sales, purchasing, and other activities. This ratio shows that the company can obtain more profits than other companies by using the same resources. The activity/efficiency ratio used is total asset turnover;

- Profitability Ratio. Profitability the ratio is a ratio that shows the final result of several policies and decisions made by the company. The profitability ratio used is ROA (rate of return on assets);

- Financial Leverage. Financial Leverage is the level of long-term creditor protection and investment. The ratio used is the ratio of debt to assets;

- Cash Position Ratio. The cash position ratio is a ratio that shows the company's cash position at a time. Cash is used by the company to facilitate its activities/operations. The ratio used is the ratio of cash to current liabilities;

- Growth Ratio. Growth ratio is a ratio that shows the percentage of the company's growth over time. The ratio used is the ratio that has increased or the percentage of net profit growth;

- Activity/Operation Ratio. Activity/operating ratio is the ratio of the company's main income-generating activities and other activities that are not investment activities and 
financing activities. The ratio used is Net Cash Flow from Operating Activities on

Sales compared to sales.

Financial distress is a condition of financial difficulties experienced by the company, starting when the company is unable to pay off its obligations to creditors or the inability to pay off debts that show negative performance and liquidity problems (Brigham and Gapenski, 1997).

The company's performance can be seen from its financial statements. Financial statements are a source of information for parties who have an interest in the company. Users of financial statements can assess whether the company is in good or bad condition.

Previous Research. Platt and Platt's (2002) research on 24 companies experiencing financial distress and 62 companies not experiencing financial distress using the logit model, proves that the variables EBITDA/sales, current assets/current liabilities, and cash flow growth rate have a negative effect on the probability of companies that will experience financial distress. While the variables of net fixed assets/total assets, long-term debt/equity, and notes payable/total assets have a positive effect on the possibility that the company will experience financial distress. The greater this ratio, the more likely the company is to experience financial distress.

Luciana and Meliza's (2003) study used 3 groups of companies and 1 group of control companies as a comparison. The four groups of companies are the group of companies experiencing negative net income for 2 consecutive years; a group of companies experiencing negative net income negative and book value of equity for 2 consecutive years; a group of companies delisted; and groups of companies that are still active and do not experience negative net income for 2 consecutive years. This study provides evidence that the ratio of net income/total assets, shareholder equity/total assets, retained earnings/total assets, and total debt/total assets can be used to predict the probability of a company experiencing financial distress.

Luciana (2004) also researched 81 companies with details of 43 companies that did not experience financial distress, 14 companies that experienced financial distress from companies that experienced negative net income for 2 consecutive years, and 24 companies that experienced financial distress. from companies that experienced negative net income negative and the book value of equity for 2 consecutive years. Meanwhile, as a control, healthy companies were selected in 2000-2001. The finding of this study is that there is a negative relationship between total liabilities/total assets (TLTA), operating activities/total assets, operating activities/total debts on the probability that the company will experience financial distress. The lower this ratio, the higher the probability of the company experiencing financial distress ( both companies that experience negative net income negative and book value of equity for 2 consecutive years and companies that experience negative net income negative and book value of equity for 2 consecutive years). While the operating activity variables/current liabilities, current assets/total assets have a positive relationship to the probability that the company will experience financial distress. The higher this ratio, the higher the probability that the company will experience financial distress (both companies experiencing negative net income negative and the book value of equity for 2 consecutive years or companies experiencing negative net income negative and a book value of equity for 2 consecutive years).

\section{METHODS OF RESEARCH}

The population used in this study is all companies listed on the Indonesia Stock Exchange during 2019-2020. Sampling was carried out using purposive sampling with the following sample selection criteria:

- Manufacturing companies that have experienced constant or increasing sales for 2 consecutive years;

- Manufacturing companies that for 2 consecutive years have net income (net income) that remains or increases. 
The data sources in this study came from financial reports, in the form of balance sheets, income statements, and cash flow statements for the 2019-2020 period, which were obtained from the Indonesia Stock Exchange.

The dependent variable used in this study is the company's financial distress condition. The company is included in the financial distress or non-financial distress group using the Altman Z-Score method. If the company has a $Z$ value $<3$ then the company is included in the group financial distress. While the company has a value of $Z 3$, then the company is included in the group non-financial distress. The $Z$ score calculation uses 5 ratios, namely: Ratio working capital to total assets; the ratio of retained earnings to total assets, a ratio of net operating income to total assets; a ratio of market equity to book value of debt; and the ratio of sales to total assets.

The profitability ratio used is the ratio profit margin. The profit margin ratio is the ratio between net operating income and net sales or the comparison between net income and sales (Riyanto, Bambang; 1995).

$$
\text { Net Profit Margin }=\frac{\text { Net Income }}{\text { Sales }}
$$

This ratio shows how big the percentage of net profit earned from each sale is. The bigger this ratio, the better because it is considered that the company's ability to earn a profit is quite high.

The liquidity ratio describes the company's ability to settle its short-term obligations. The liquidity ratios used are:

$$
\text { Working Capital to Assets Ratio }=\frac{\text { WorkingCapital }}{\text { AssetsTotal }}
$$

This ratio shows how much working capital or assets are obtained from each total asset. The bigger this ratio, the better because the company's ability to settle its short-term obligations is high.

Profitability ratios show the final result of several policies and decisions. The profitability ratios used are as follows:

$$
\text { Rate of Return on Assets }=\frac{\text { NetIncome }}{\text { AssetsTotal }}
$$

This ratio shows how far the company's ability to generate profits from the use of all its assets; the higher this ratio, the better.

Financial leverage is the level of long-term creditor protection and investment. Financial leverage is a ratio that is intended to measure to what extent the company's assets are financed with debt. The ratio financial leverage used is as follows:

$$
\text { Debt to Total Assets Ratio }=\frac{\text { Debt }}{\text { AssetsTotal }}
$$

This ratio shows the extent to which debt can be covered by assets; the bigger the ratio, the safer (solvable). You can also read how much debt is compared to assets. To be safe the portion of the debt to assets must be smaller.

The cash position ratio used is the ratio of cash to current liabilities.

$$
\text { Cash Position Ratio }=\frac{\text { Cash }}{\text { CurrentDebt }}
$$


Explains that the higher the cash, the greater the guarantee to meet the current debt obligations. Therefore, the risk will be lower in financial distress.

This ratio describes the percentage growth of company posts from year to year. The ratio used is the ratio that reflects the increase in net income or the percentage growth in net income. The growth ratio used is as follows:

$$
\text { Sales Growth Ratio }=\frac{\text { Sales }_{t}-\text { Sales }_{t-1}}{\text { Sales }_{t-1}}
$$

The financial ratio of the cash flow statement information used in this study is the Activity/Operations Ratio. Activities/operations are the main income-generating activities of the company and other activities that are not investing and financing activities. Operating activities include:

$$
\text { Net Cash Flow from Operating Activities on Sales }=\frac{\text { Net Cash Flow from Operating Activities }}{\text { Sales }}
$$

\section{RESULTS AND DISCUSSION}

The results of the test using the overall model fit test (overall model fit test) showed that there was no difference between the two -2LogL so that it could be concluded that the addition of independent variables into the model did not improve the model fit.

Table 1 - Results Overall Model Fit Test

\begin{tabular}{|l|l|}
\hline Description & Value \\
\hline-2 loglikelihood at the beginning (block number=0) & 199.917 \\
\hline-2 loglikelihood at the end (block number=1) & 199.917 \\
\hline
\end{tabular}

Based on Table 1, the value is -2loglikelihood at the beginning (block number $=0$ ) is 199.917. This model only includes constants, significant at $=5 \%$, meaning that the model with only constants does not fit enough data. The value of -2likelihood at the end (number block $=1$ ) is 199.917. This model includes constants and 7 independent variables, and is significant at $=5 \%$, meaning that this model fits the data.

The results of the Hosmer and Lemeshow's Goodness of Fit Test in table 2 show that the value of the Hosmer and Lemeshow Test is 10,772 with a significant probability of 0.215 $>0.05$. This means that the logistic regression model in this study can be used to predict the possibility of financial distress in manufacturing companies listed on the Indonesia Stock Exchange in 2019 - 2020.

Table 2 - Results of Holsmer and LemeshowTest

\begin{tabular}{|l|l|l|l|}
\hline Hosmer and Lemeshow Test \\
\hline Step & Chi-square & Df & Sig. \\
\hline $10,772.215$ & & 8 & 1 \\
\hline
\end{tabular}

\begin{tabular}{|c|c|c|c|}
\hline \multicolumn{4}{|c|}{ Model Summary } \\
\hline Step & -2 Log likelihood & Cox \& Snell R Square & Nagelkerke R Square \\
\hline 1 & $148939^{a}$ & .353 & .219 \\
\hline
\end{tabular}

Table 3 - Nagelkerke R Square

Cox \& Snell Square is a measure that mimics $R^{2}$ in multiple regression. Whereas Nagelkerke $R$ Square is a modification of the Cox \& Snellcoefficients. So Nagelkerke $R$ Square is intended to determine the magnitude of the prediction variation from the independent variable to the dependent can be seen in its value, between 0 to 1 . 
The coefficient of determination essentially measures how far the model's ability on the independent variable is Profitability, Liquidity, Profitability, Financial Leverage, Cash Position, Growth, Activities together explain the variation of the dependent variable (financial distress). The test results with SPSS can be seen in the table 2.

Based on Table 3, it appears that the value of Nagelkerke R Square is 0.353 , which means that the dependent variable can be explained by the independent variable by $35.3 \%$, while the remaining $64.7 \%$ is explained by other variables, outside the variables in this study. This shows that together the variation of the independent variables can explain the variation of the variable financial distress by $35.3 \%$.

Matrix The classification matrix shows the predictive power of the regression model to predict the possibility of a company experiencing financial distress.

Table 4 - Results of the Classification Matrix

\begin{tabular}{|c|c|c|c|c|c|}
\hline \multicolumn{6}{|c|}{ Classification Table $^{\mathrm{S}}$} \\
\hline \multirow{6}{*}{ Step 1} & \multirow{3}{*}{\multicolumn{2}{|c|}{ Observed }} & Pre & & \\
\hline & & & \multicolumn{2}{|c|}{ Fin_Distress } & \multirow{3}{*}{ Percentage Correct } \\
\hline & & & 0 & 1 & \\
\hline & \multirow[b]{2}{*}{ Fin_Distress } & 0 & 15 & 24 & \\
\hline & & 1 & 4 & 163 & 97.6 \\
\hline & \multicolumn{2}{|c|}{ Overall Percentage } & & & 86.4 \\
\hline
\end{tabular}

Based on Table 4, the predictions of companies experiencing financial distress are 163 companies, with a model accuracy of $97.6 \%$. While the predictive power of the regression model to predict the possibility of companies not experiencing financial distress is $38.5 \%$, there are 15 companies. Overall, the predictive power of the regression model is $86.4 \%$, meaning that the independent variable can predict the regression model statistically at $86.4 \%$.

Omnibus Test of Model Coefficient is carried out to test the significance simultaneously in logistic regression analysis. The test was conducted to test whether the independent variables in the study had a joint effect on the dependent variable. The way to find out the results of the simultaneous test is to look at the results of the logistic regression by looking at the significance value. If the significance value is $<0.05$ then $\mathrm{H}_{0}$ is accepted, but if the significance value is $<0.05$ then $\mathrm{H}_{0}$ is rejected or $\mathrm{H}_{\mathrm{a}}$ is accepted.

Table 5 - Hypothesis Test Results Simultaneous

\begin{tabular}{|l|l|l|l|l|}
\hline Omnibus Tests of Model Coefficients & Chi-square & df & Sig. \\
\hline \multirow{3}{*}{ Step 1} & Step & 50,978 & 7 & 000 \\
\cline { 2 - 6 } & Block & 50,978 & 7 & 000 \\
\cline { 2 - 6 } & Model & 50,978 & 7 & 000 \\
\hline
\end{tabular}

Based on Table 5, it can be explained that the sig model value is 0.000 . This value is smaller than the value of $=5 \%$, so it can be concluded that the independent variables simultaneously affect the probability of financial distress.

Partial hypothesis testing using logistic regression test conducted on all independent variables. The test results are as follows:

Table 6 - Partial Hypothesis Test Results

\begin{tabular}{|c|c|c|c|c|c|c|c|c|c|}
\hline \multirow{2}{*}{\multicolumn{2}{|c|}{ Variables in the Equation }} & \multirow{2}{*}{$B$} & \multirow{2}{*}{ SE } & \multirow{2}{*}{ Wald } & \multirow{2}{*}{ df } & \multirow{2}{*}{ Sig. } & \multirow{2}{*}{$\operatorname{Exp}(B)$} & \multicolumn{2}{|c|}{$95 \%$ for $\mathrm{EXP}(\mathrm{B})$} \\
\hline & & & & & & & & Lower & Upper \\
\hline \multirow{8}{*}{ Step $1^{a}$} & Profitability & .000 & .000 & .084 & 1 & .771 & 1,000 & 1,000 & 1,000 \\
\hline & \begin{tabular}{|l|} 
Liquidity \\
\end{tabular} & .000 & .000 & 1.378 & 1 & 240 & 1,000 & 1,000 & 1,000 \\
\hline & Profitability & -.001 & .001 & 1.094 & 1 & .998 & .999 & 296 & 1,001 \\
\hline & Fin_Leverage & .000 .674 .412 & & & 1 & .000 & $1,0001,000$ & & 1,000 \\
\hline & Posisi_Kas & .000 & .000 & 2,488 & 1 & .115 & 1,000 & .999 & 1,000 \\
\hline & Growth & .000 .007 & & 7,280 & 1 & .000 & 1,000 & 1,000 & 1,001 \\
\hline & Activity & .000 & .000 & 11328 & 1 & .001 & 1,000 & 1,000 & 1,000 \\
\hline & Constant & 3,156 , & 516 & 37,391 & 1 & 000 & 23,481 & & \\
\hline
\end{tabular}

a. Variable(s) entered on step 1: Profitability, Liquidity, Profitability, Fin_Leverage, Cash_Position, Growth, Activity. 
Based on Table 6, the logistic regression equation can be arranged, as follows:

$$
\mathrm{FD}=3.156+0.000 \times 1+0.000 \times 2-0.001 \times 3+0.000 \times 4+0.000 \times 6+0.000 \times 7
$$

From the logistic regression equation, it can be seen that the company's financial distress condition is positively related to profitability, Liquidity, Profitability, Leverage, Growth, Activity, while the cash position is negatively related. The result of the regression coefficient of the profitability variable is 0.000 with a significance value of 0.771 so that it can be interpreted that the profitability variable has no significant effect on the probability of financial distress. Profitability has a positive relationship to financial distress so that it can be interpreted that the higher the level of profitability obtained, the higher the tendency of the company to experience financial distress.

The result of the regression coefficient of the liquidity variable is 0.000 with a significance value of 0.240 so that it can be interpreted that the liquidity variable has no significant effect on the probability of financial distress. Liquidity has a positive relationship to financial distress so that it can be interpreted that the higher the level of liquidity obtained, the higher the tendency of the company to experience financial distress.

The result of the regression coefficient of the profitability variable is -0.001 with a significance value of 0.296 , so it can be interpreted that the profitability variable has no significant effect on the probability of financial distress. Profitability has a negative relationship to financial distress so that it can be interpreted that the higher the level of profitability obtained, the lower the tendency of the company to experience financial distress.

The result of the regression coefficient of the variable is Financial Leverage 0.000 with a significance value of 0.412 , so it can be interpreted that the variable Financial Leverage has no significant effect on the probability of financial distress. Financial Leverage has a positive relationship to financial distress so that it can be interpreted that the higher the level of Financial Leverage obtained, the higher the tendency of the company to experience financial distress.

The result of the regression coefficient of the variable is Cash Position 0.000 with a significance value of 0.115 , so it can be interpreted that variable Cash Position has not had a significant effect on the probability of financial distress. Cash Position has a positive relationship to financial distress so that it can be interpreted that the higher the level of Cash Position obtained, the higher the company's tendency to experience financial distress.

The results the regression coefficient of the variable Growth of 0.000 with a significance value of 0.007 , so it can be interpreted that the variable growth has a significant effect on the probability of financial distress. Growth has a positive relationship to financial distress so that it can be interpreted that the higher the rate of growth obtained, the higher the company's tendency to experience financial distress.

Results of the regression coefficient of the variable Activity of 0.000 with a significance value of 0.001 , so it can be interpreted that the variable activity has a significant effect on the probability of financial distress. Activities have a positive relationship to financial distress so that it can be interpreted that the higher the level of activity obtained, the higher the company's tendency to experience financial distress.

The results showed that the variables of profitability, liquidity, profitability, financial leverage, and cash position do not have a significant effect on financial distress, although these variables have a positive relationship to financial distress. This finding is in line with the findings of previous research conducted by Plat \& Plat (2002).

The growth and activity ratio has a significant influence. The growth ratio has a significant effect and has a positive relationship to financial distress, meaning that the higher the growth, the higher the risk of financial distress. This can happen because the higher the company's growth, the more risky the company will fail to meet capital and invest. Or it could also happen the other way around if the company's growth is getting lower, the risk will be lower financial distress. The activity ratio also has a significant effect and has a positive direction on financial distress. This means that this condition can occur because the higher the company's activities, the higher the financial distress. 


\section{CONCLUSION}

The logistic regression model in this study can be used to predict financial distress in manufacturing companies listed on the Indonesia Stock Exchange in 2019-2020 during the pandemic.

There is a joint influence between Profitability, Liquidity, Profitability, Financial Leverage, Cash Position, Growth, and Activity on Financial Distress in manufacturing companies listed on the Indonesia Stock Exchange in 2019 - 2020 during the pandemic.

There was no effect of Profitability, Liquidity, Profitability, Financial Leverage, Cash Position, on Financial Distress in manufacturing companies listed on the Indonesia Stock Exchange in 2019 - 2020 during the pandemic.

There is an effect of Growth and Activity Ratio on Financial Distress in manufacturing companies listed on the Indonesia Stock Exchange in 2019 - 2020 during the pandemic.

Further Research:

- Adding the period of research data used is only using financial data during the pandemic, which may still occur for several years to come. The ability to detect financial distress will be better if using panel data that is quite long;

- Adding ratios or variables used can be from ratios other than those already used in this study so that the results can be compared.

\section{REFERENCES}

1. Altman, Edward I. 1968. Financial Ratios, Discriminant Analysis and the Prediction of Corporate Bankruptcy, the Journal of Finance, September, Volume 23, Number 4, New York: American Finance Association.

2. Brahmana, Rajendra K. 2007. Identifying Financial Distress Conditions in Indonesia Manufacturing Industry, e-Journals of the Indonesian-United Kingdom Student Association, London, October 2007.

3. Brigham, Gapenski. 1997. Financial Management: Theory And Practice. $8^{\text {th }}$ Ed.Fort Worth: The Dryden Press.

4. Damodaran, Aswath. 2006. The Cost of Distress: Survival, Truncation Risk and Valuation. Paper Stern School of Business January.

5. Fahmi, I. 2015. Introduction to Financial Management Theory and Questions and Answers. 4th Edition Bandung: Alphabeta.

6. Foster, George, 1986. Financial Statement Analysis, Second Edition, New Jersey: Prentice-Hall International.

7. Gamayuni, RR 2015. The Effect of Intangible Assets, Financial Performance and Financial Policies on the Firm Value. International Journal of Scientific \& Technology Research. 4(1). pp. 202-212.

8. Ghozali, Imam. 2002. Application of Multivariate Analysis with SPSS Programs. Diponegoro University Publishing Agency, Semarang.

9. Gujarati, Damodar. 1991. Basic Econometrics. Jakarta: Erlangga.

10. Hanafi, M Mamduh.. and Abdul Halim. 2003. Analysis of Financial Statements. Yogyakarta: UPP AMP YKPN.

11. Hanifah, O. 2013. The Effect of Corporate Governance Structure and Financial Indicators on Financial Distress Conditions. "Undip maxi journal, h. 25-53.

12. Lau, Ling, Amy Hing, 1987. A FiveStates Financial Distress Prediction Model, Journal of Accounting Research, Volume 25, Number 1, Oklahoma: Blackwell Publishing Limited.

13. Mulyadi, 2002. Auditing, Book Two, Sixth Edition, Salemba Empat, Jakarta.

14. Munawir. S. 1998. Analysis of Financial Statements. Yogyakarta: Liberty publisher.

15. Platt HD, Platt MB. 2002. Predicting corporate financial distress: reflecting on choicebased sample bias. Journal of Economics and Finance 26(2):184-199.

16. Prastowo, Dwi and Rifka. 2005. Financial Statement Analysis. Yogyakarta: UPP AMP YKPN. 
17. Riyanto, Bambang. 1995. Fundamentals of Corporate Spending. Yogyakarta: Gadjah Mada Publishing Agency Foundation.

18. Sari, Ayu Kurnia. 2016. Analysis of Financial Distress in Indonesian Stock Exchange Companies. Scientific Journal of Research Science Vol.2 No. 2 June 2016.

19. Sawir, Agnes. 2001. Financial Performance Analysis and Corporate Financial Planning. Jakarta: PT. Main Library Gramedia.

20. Schuppe, Walter $p$ (2005), "Leading a Turnaround", the Secured Lender.

21. Sofyan Syafri Harahap. 1997. Critical Analysis of Financial Statements. Jakarta: PT Raja Grafindo Persada.

22. Spica, Luciana Almilia and Meliza Silvy. 2003. Analysis of Factors Affecting Post-IPO Company Status with Multinomial Logit Analysis. Indonesian Journal of Economics and Business (JEBI). Volume 18 no 4.

23. Spica, Luciana Almilia. 2006. Predicting the Financial Distress Condition of Go Public Companies Using Multinomial Logit Analysis. Indonesian Journal of Economics and Business (JEBI). Volume 12 no 1.

24. Sugiyono. 2005. Business Research Method. Bandung: Alphabeta. 